\title{
ANALISIS FINANCIAL DISTRESS PADA BANK UMUM SYARIAH DI INDONESIA
}

\author{
Aditya Putra Rahadi ${ }^{1}$ \\ Sufyati HS ${ }^{2}$ \\ ${ }^{1,2}$ Fakultas Ekonomi dan Bisnis Universitas Nasional
}

Email: $\underline{\text { rahadiaditya@ rocketmail.com }}{ }^{1}, \underline{\text { sufyati.yusuf@gmail.com }}^{2}$

\begin{abstract}
ABSTRAK
Penelitian ini bertujuan untuk menganalisis financial distress pada bank umum syariah di Indonesia. Dengan menggunakan metode purposive sampling, diperoleh sampel sebanyak 11 bank umum syariah dengan data yang mencakup periode 2012-2016. Data dianalisis dengan menggunakan model Altman Z-Score modifikasi. Hasil penelitian menunjukan bahwa: (1) bank umum syariah yang dikategorikan sehat terdiri dari empat bank di tahun 2012, empat bank di tahun 2013, lima bank di tahun 2014, enam bank di tahun 2015, dan empat bank di tahun 2016; (2) bank umum syariah yang berada di dalam grey area terdiri dari tujuh bank di tahun 2012, tujuh bank di tahun 2013, enam bank di tahun 2014, lima bank di tahun 2015, dan tujuh bank di tahun 2016; (3) bank umum syariah yang secara konsisten dikategorikan sehat selama periode 2012-2016 adalah Bank Panin Syariah dan BCA Syariah; dan (4) bank umum syariah yang selalu berada di grey area selama periode 2012-2016 adalah Bank Muamalat Indonesia, Bank Syariah Mandiri, BRI Syariah, Bank Syariah Bukopin dan BNI Syariah.
\end{abstract}

Kata kunci: Financial distress, Altman Z-score, grey area

\section{ABSTRACT}

This research aims to analyze the financial distress in sharia commercial banks in Indonesia. By using purposive sampling method, a sample of 11 sharia commercial banks with data covering the 2012-2016 period was obtained. Data were analyzed using a modified Altman Z-Score model. The results of the study showed that: (1) healthy categorized sharia commercial banks consist of four banks in 2012, four banks in 2013, five banks in 2014, six banks in 2015, and four banks in 2016; (2) sharia commercial banks in the grey area consist of seven banks in 2012, seven banks in 2013, six banks in 2014, five banks in 2015, and seven banks in 2016; (3) sharia commercial banks that consistently categorized as healthy during the 2012-2016 period are Bank Panin Syariah and BCA Syariah; and (4) sharia commercial banks that always in the gray area during the 2012-2016 period are Bank Muamalat Indonesia, Bank Syariah Mandiri, BRI Syariah, Bank Syariah Bukopin and BNI Syariah.

Keywords: Financial distress, Altman Z-score, grey area

\section{PENDAHULUAN}

Perkembangan sektor perbankan di Indonesia telah memunculkan suatu dualbanking system dalam kerangka Arsitektur Perbankan Indonesia (API). Sistem tersebut menghadirkan alternatif jasa perbankan lengkap yang terdiri dari sistem perbankan konvensional dan syariah secara sinergis dan simultan untuk memenuhi kebutuhan 
mobilisasi dana dalam rangka meningkatkan kemampuan pembiayaan bagi berbagai sektor dalam perekonomian nasional. Sistem perbankan syariah itu sendiri berbeda dari sistem perbankan konvensional karena pengoperasiannya dilakukan berdasarkan prinsip bagi hasil yang mengedepankan keadilan dalam bertransaksi, etika dalam berinvestasi, nilai persaudaraan dan kebersamaan dalam berproduksi, serta menghindari spekulasi dalam bertransaksi (Bank Indonesia, 2008).

Berdasarkan data yang diperoleh dari Bank Indonesia (2008), perbankan syariah mengalami perkembangan yang cukup impresif dengan rata-rata pertumbuhan aset tahunan mencapai lebih dari $65 \%$ selama lima tahun berturut-turut, sehingga industri tersebut diekspektasikan memiliki prospek yang baik di masa mendatang, termasuk dari segi profitabilitas. Berikut ini disajikan data retained earning dari bank-bank umum syariah di Indonesia untuk periode 2012-2016.

Tabel 1. Retained Earning Bank Umum Syariah di Indonesia

Periode 2012-2016 (Dalam Jutaan Rupiah)

\begin{tabular}{|c|c|r|r|r|r|r|}
\hline No & Kode Bank & \multicolumn{1}{c|}{$\mathbf{2 0 1 2}$} & \multicolumn{1}{c|}{$\mathbf{2 0 1 3}$} & \multicolumn{1}{c|}{$\mathbf{2 0 1 4}$} & \multicolumn{1}{c|}{$\mathbf{2 0 1 5}$} & \multicolumn{1}{c|}{$\mathbf{2 0 1 6}$} \\
\hline 1 & BMI & 1.120 .894 & 1.596 .740 & 684.634 & 162.708 & 243.220 \\
\hline 2 & BSM & 2.722 .182 & 3.373 .423 & 3.445 .201 & 3.242 .502 & 3.567 .915 \\
\hline 3 & BSMI & 301.649 & 149.739 & 17.635 & 6.836 .668 & 7.070 .143 \\
\hline 4 & BRIS & 89.564 & 219.128 & 228.843 & 349.090 & 519.299 \\
\hline 5 & BSB & -177.297 & 292.619 & 501.281 & -121.587 & -55.965 \\
\hline 6 & BPS & 46.849 & 25.995 & 96.933 & 150.456 & 169.997 \\
\hline 7 & BJBS & -9.557 & 18.757 & 22.270 & 32.312 & -382.598 \\
\hline 8 & BVS & 42.534 & 46.609 & 25.315 & 2.652 & -15.492 \\
\hline 9 & BCAS & 18.958 & 31.659 & 44.609 & 68.045 & 104.862 \\
\hline 10 & BNIS & 175.967 & 283.680 & 408.500 & 607.025 & 861.547 \\
\hline 11 & MSI & 131.542 & 143.368 & 199.321 & 95.098 & -258.836 \\
\hline
\end{tabular}

(Sumber: Data diolah, 2017)

Berdasarkan tabel di atas, perkembangan retained earning dari bank-bank umum syariah di Indonesia yang dapat digunakan untuk mendanai kegiatan operasional dan investasinya justru mengalami perkembangan yang cukup lambat selama periode 20122016. Bahkan, ada pula bank-bank syariah yang justru mengalami penurunan retained earning hingga ke nilai negatif. Hal tersebut perlu diwaspadai mengingat laba bersih yang bernilai negatif selama beberapa tahun terakhir dapat mengindikasikan adanya financial distress (Almilia, 2006).

Menurut Platt dan Platt (2002) dalam Audina dan Sufyati (2018), financial distress merupakan suatu penurunan kondisi keuangan sebelum terjadinya kebangkrutan atau likuidasi. Oleh karena setiap perusahaan bertujuan untuk mempertahankan kelangsungan 
hidupnya dalam jangka panjang, maka financial distress merupakan hal-hal yang harus dihindari oleh setiap perusahaan tersebut, termasuk perusahaan di sektor perbankan berbasis syariah, dalam rangka menghindari terjadinya kebangkrutan (bankruptcy). Undang-Undang Nomor 10 Tahun 1998 tentang Perbankan juga telah mewajibkan bank untuk memelihara tingkat kesehatannya karena merupakan cerminan dari kinerja bank itu sendiri yang menjadi kepentingan bagi para stakeholders.

Dalam rangka mendeteksi gejala kebangkrutan untuk menjamin kelangsungan hidup bank-bank umum syariah di Indonesia dalam jangka panjang, perlu dilakukan penelitian untuk menganalisis financial distress dari bank-bank umum syariah tersebut.

\section{TINJAUAN PUSTAKA}

\section{Financial Distress}

Platt dan Platt (2002) dalam Audina dan Sufyati (2018) mendefinisikan financial distress sebagai suatu penurunan kondisi keuangan sebelum terjadinya kebangkrutan atau likuidasi. Menurut Wruck (1990) dalam Manurung (2012), financial distress terjadi ketika arus kas suatu perusahaan tidak mampu memenuhi kewajibannya. Sejalan dengan hal tersebut, Whitaker (1999) dalam Choirina dan Yuyetta (2015) menyebutkan bahwa financial distress diindikasikan oleh arus kas yang lebih kecil daripada utang jangka panjang yang telah jatuh tempo. Sementara itu, Almilia (2006) mengemukakan bahwa financial distress dapat diindikasikan oleh adanya laba bersih yang negatif selama beberapa tahun.

Ditinjau dari aspek keuangan, terdapat tiga faktor yang menyebabkan terjadinya financial distress, yaitu kekurangan modal, beban utang dan bunga yang besar, serta terjadinya kerugian (Rodoni dan Ali, 2014). Menurut Damodaran (2001) dalam Audina dan Sufyati (2018), penyebab terjadinya financial distress antara lain kesulitan arus kas, jumlah utang yang besar dan kerugian operasional selama beberapa tahun.

\section{Metode Altman Z-Score}

Menurut Supardi (2003:11), Altman adalah suatu diskriminan yang berguna untuk memprediksikan kebangkrutan suatu perusahaan dengan menggunakan Z-Score. Z-Score itu sendiri didefinisikan oleh Supardi (2003:73) sebagai skor hitung dari standar kali atas berbagai rasio keuangan yang menunjukkan probabilitas kebangkrutan dari suatu perusahaan. Altman's Z-score disebut juga sebagai Altman Bankrupty Prediction Model Z- 
score, yakni suatu model yang merumuskan kapan suatu perusahaan akan mengalami kebangkrutan (Harahap, 2010).

Dalam perkembangannya, terdapat tiga model rumus yang dapat digunakan untuk menghitung Altman Z-Score, yaitu sebagai berikut.

\section{Model Altman Pertama}

Model ini dapat digunakan untuk memprediksi kebangkrutan pada perusahaan manufaktur yang telah go-public.

$$
Z=1,2 X_{1}+1,4 X_{2}+3,3 X_{3}+0,6 X_{4}+1,0 X_{5}
$$

(Sumber: Altman, 1968)

Keterangan:

$$
\begin{aligned}
& \mathrm{X}_{1}=\text { Working capital to total asset } \\
& \mathrm{X}_{2}=\text { Retained } \text { earning } \text { to total asset } \\
& \mathrm{X}_{3}=\text { Earning before interest and tax to total asset } \\
& \mathrm{X}_{4}=\text { Market value of equity to book value of total debt } \\
& \mathrm{X}_{5}=\text { Sales to total asset } \\
& \mathrm{Z}=\text { Z-Score untuk model Altman pertama }
\end{aligned}
$$

Z-score yang diperoleh dari rumus di atas akan dikelompokkan ke dalam tiga kategori berikut.

a. Z-score yang lebih kecil daripada 1,8 $(\mathrm{Z}<1,8)$ mengindikasikan bahwa perusahaan memiliki probabilitas yang tinggi untuk mengalami kebangkrutan.

b. Z-score yang berada di antara 1,8 dan $2,99(1,8<\mathrm{Z}<2,99)$ mengindikasikan bahwa perusahaan berada di zona abu-abu (grey area), sehingga tidak dapat dipastikan apakah perusahaan tersebut dikategorikan sebagai perusahaan yang sehat atau perusahaan yang berkemungkinan untuk mengalami kebangkrutan.

c. Z-score yang lebih besar daripada 2,99 ( $\mathrm{Z}>2,99)$ mengindikasikan bahwa perusahaan berada dalam kondisi yang sehat dengan probabilitas kebangkrutan yang rendah.

\section{Model Altman Revisi}

Model ini tidak hanya dapat digunakan pada perusahaan manufaktur yang telah gopublic, tetapi juga dapat digunakan pada perusahaan-perusahaan swasta.

$$
Z^{\prime}=0,717 X_{1}+0,847 X_{2}+3,107 X_{3}+0,42 X_{4}+0,998 X_{5}
$$

(Sumber: Altman, 1983) 
Keterangan:

$$
\begin{aligned}
& \mathrm{X}_{1}=\text { Working capital to total asset } \\
& \mathrm{X}_{2}=\text { Retained earning to total asset } \\
& \mathrm{X}_{3}=\text { Earning before interest and tax to total asset } \\
& \mathrm{X}_{4}=\text { Book value of equity to book value of total debt } \\
& \mathrm{X}_{5}=\text { Sales to total asset } \\
& \mathrm{Z}^{\prime}=\text { Z-Score untuk model Altman revisi }
\end{aligned}
$$

Z-score dari rumus di atas akan dikelompokkan ke dalam tiga kategori berikut.

a. Z-score yang lebih kecil daripada $1,23\left(Z^{\prime}<1,23\right)$ mengindikasikan bahwa perusahaan memiliki probabilitas yang tinggi untuk mengalami kebangkrutan.

b. Z-score yang berada di antara 1,23 dan 2,9 $\left(1,23<Z^{\prime}<2,9\right)$ mengindikasikan bahwa perusahaan berada di zona abu-abu (grey area), sehingga tidak dapat dipastikan apakah perusahaan tersebut dikategorikan sebagai perusahaan yang sehat atau perusahaan yang berkemungkinan untuk mengalami kebangkrutan.

c. Z-score yang lebih besar daripada $2,9\left(Z^{\prime}>2,9\right)$ mengindikasikan bahwa perusahaan berada dalam kondisi yang sehat dengan probabilitas kebangkrutan yang rendah.

\section{Model Altman Modifikasi}

Dalam model ini, Altman, et al. (1995) mengeliminasi variabel $\mathrm{X}_{5}$, yakni rasio penjualan terhadap total aset (sales to total asset) karena nilainya sangat bervariasi di berbagai industri.

$$
Z "=6,56 X_{1}+3,26 X_{2}+6,72 X_{3}+1,05 X_{4}
$$

(Sumber: Altman, et al.,1995)

Keterangan:

$$
\begin{aligned}
& \mathrm{X}_{1}=\text { Working capital to total asset } \\
& \mathrm{X}_{2}=\text { Retained } \text { earning to total asset } \\
& \mathrm{X}_{3}=\text { Earning before interest and tax to total asset } \\
& \mathrm{X}_{4}=\text { Book value of equity to book value of total debt } \\
& Z \text { " }=\text { Z-Score untuk model Altman modifikasi }
\end{aligned}
$$


Z-score dari rumus di atas akan dikelompokkan ke dalam tiga kategori berikut.

a. Z-score yang lebih kecil daripada $1,1(\mathrm{Z} "<1,1)$ mengindikasikan bahwa perusahaan memiliki probabilitas yang tinggi untuk mengalami kebangkrutan.

b. Z-score yang berada di antara 1,1 dan 2,6 (1,1<Z" < 2,6) mengindikasikan bahwa perusahaan berada di zona abu-abu (grey area), sehingga tidak dapat dipastikan apakah perusahaan tersebut dikategorikan sebagai perusahaan yang sehat atau perusahaan yang berkemungkinan untuk mengalami kebangkrutan.

c. Z-score yang lebih besar daripada 2,6 (Z" > 2,6) mengindikasikan bahwa perusahaan berada dalam kondisi yang sehat dengan probabilitas kebangkrutan yang rendah.

\section{METODOLOGI PENELITIAN}

Data yang digunakan dalam penelitian ini adalah data panel yang berasal dari sumber sekunder, yakni dari laporan keuangan bank-bank umum syariah yang bersangkutan selama periode penelitian, yaitu periode 2012-2016. Periode penelitian ini dipilih karena dinilai dapat mencerminkan kondisi teraktual yang dialami oleh bank-bank umum syariah tersebut.

Populasi penelitian ini adalah seluruh bank umum syariah yang terdaftar di Bursa Efek Indonesia pada periode 2012-2016, sehingga diperoleh 12 perusahaan sebagai populasi penelitian. Pengambilan sampel dilakukan dengan menggunakan metode purposive sampling, yaitu dengan kriteria yang menyatakan bahwa perusahaan harus telah berdiri selama lebih dari lima tahun, yakni sekurang-kurangnya sejak tahun 2012 hingga 2016 secara berturut-turut. Berdasarkan kriteria tersebut, sampel penelitian ini terdiri dari 11 perusahaan. Oleh karena periode pengamatan berada pada rentang tahun 2012-2016, maka secara total, terdapat 55 pengamatan yang dianalisis financial distress-nya dalam penelitian ini dengan menggunakan model Altman Z-Score modifikasi.

\section{HASIL DAN PEMBAHASAN}

Data berbagai rasio keuangan yang digunakan untuk mengukur Z-Score dalam penelitian ini disajikan pada tabel berikut. 
Tabel 2. Rasio Keuangan Bank Umum Syariah di Indonesia pada Periode 2012-2016

\begin{tabular}{|c|c|c|c|c|c|c|c|c|c|c|c|c|c|c|c|c|c|c|c|c|c|}
\hline \multirow[t]{2}{*}{ No. } & \multirow{2}{*}{$\begin{array}{l}\text { Kode } \\
\text { Bank }\end{array}$} & \multicolumn{5}{|c|}{ Working Capital to Total Asset } & \multicolumn{5}{|c|}{ Retained Earning to Total Asset } & \multicolumn{5}{|c|}{ Earning Before Tax to Total Asset } & \multicolumn{5}{|c|}{$\begin{array}{l}\text { Book Value of Equity to } \\
\text { Book Value of Total Debt }\end{array}$} \\
\hline & & 2012 & 2013 & 2014 & 2015 & 2016 & 2012 & 2013 & 2014 & 2015 & 2016 & 2012 & 2013 & 2014 & 2015 & 2016 & 2012 & 2013 & 2014 & 2015 & 2016 \\
\hline 1 & BMI & 0,24 & 0,18 & 0,24 & 0,21 & 0,20 & 0,024 & 0,029 & 0,010 & 0,002 & 0,004 & 0,011 & 0,004 & 0,001 & 0,001 & 0,002 & 0,273 & 0,310 & 0,323 & 0,342 & 0,323 \\
\hline 2 & BSM & 0,14 & 0,16 & 0,24 & 0,24 & 0,27 & 0,050 & 0,052 & 0,051 & 0,046 & 0,045 & 0,020 & 0,013 & 0,001 & 0,005 & 0,005 & 0,455 & 0,440 & 0,592 & 0,568 & 0,569 \\
\hline 3 & BSMI & 0,21 & 0,18 & 0,18 & 0,39 & 0,45 & 0,036 & 0,016 & 0,002 & 0,087 & 0,085 & 0,030 & 0,021 & 0,003 & 0,020 & 0,026 & 0,293 & 0,404 & 0,609 & 0,236 & 0,231 \\
\hline 4 & BRIS & 0,18 & 0,17 & 0,21 & 0,30 & 0,33 & 0,006 & 0,012 & 0,011 & 0,014 & 0,018 & 0,009 & 0,010 & 0,007 & 0,009 & 0,006 & 0,311 & 0,379 & 0,304 & 0,364 & 0,296 \\
\hline 5 & BSB & 0,21 & 0,17 & 0,23 & 0,22 & 0,27 & $(0,159)$ & 0,067 & 0,097 & $(0,020)$ & $(0,007)$ & 0,006 & 0,006 & 0,002 & 0,006 & 0,006 & 0,081 & 0,287 & 0,604 & 0,722 & 0,607 \\
\hline 6 & BPS & 0,27 & 0,35 & 0,22 & 0,19 & 0,24 & 0,021 & 0,006 & 0,015 & 0,021 & 0,019 & 0,016 & 0,007 & 0,015 & 0,010 & 0,008 & 2,329 & 1,306 & 1,203 & 1,373 & 1,165 \\
\hline 7 & BJBS & 0,27 & 0,19 & 0,24 & 0,19 & 0,30 & $(0,002)$ & 0,004 & 0,003 & 0,005 & $(0,051)$ & $(0,005)$ & 0,008 & 0,005 & 0,002 & $(0,073)$ & 1,046 & 0,882 & 1,062 & 1,986 & 0,931 \\
\hline 8 & BVS & 0,46 & 0,33 & 0,22 & 0,22 & 0,23 & 0,045 & 0,035 & 0,017 & 0,001 & $(0,009)$ & 0,011 & 0,003 & $(0,017)$ & $(0,023)$ & $(0,017)$ & 0,943 & 1,549 & 1,858 & 1,462 & 0,837 \\
\hline 9 & BCAS & 0,36 & 0,29 & 0,27 & 0,30 & 0,29 & 0,011 & 0,015 & 0,014 & 0,015 & 0,020 & 0,006 & 0,008 & 0,005 & 0,007 & 0,009 & 1,185 & 1,140 & 1,929 & 2,674 & 2,619 \\
\hline 10 & BNIS & 0,25 & 0,21 & 0,21 & 0,22 & 0,27 & 0,016 & 0,019 & 0,020 & 0,026 & 0,030 & 0,012 & 0,012 & 0,011 & 0,013 & 0,013 & 0,543 & 0,339 & 0,632 & 0,669 & 0,530 \\
\hline 11 & MSI & 0,05 & 0,35 & 0,32 & 0,32 & 0,50 & 0,063 & 0,062 & 0,081 & 0,054 & $(0,192)$ & 0,027 & 0,025 & 0,031 & $(0,224)$ & $(0,107)$ & 0,855 & 1,848 & 2,014 & 2,739 & 1,831 \\
\hline
\end{tabular}

(Sumber: Data diolah, 2017)

Berdasarkan data di atas, perusahaan dengan nilai working capital to total asset terbesar selama periode pengamatan adalah Bank Victoria Syariah (2012), Bank Panin Syariah (2013), Maybank Syariah Indonesia (2013, 2014 dan 2016), dan Bank Syariah Mega Indonesia (2015). Adapun perusahaan dengan nilai working capital to total asset terendah selama periode pengamatan adalah Maybank Syariah Indonesia (2012), Bank Syariah Mandiri (2013), Bank Syariah Mega Indonesia (2014), Bank Panin Syariah dan BJB Syariah (2015), serta Bank Muamalat Indonesia (2016)

Perusahaan dengan nilai retained earning to total asset terbesar selama periode pengamatan adalah Maybank Syariah Indonesia (2012), Bank Syariah Bukopin (2013-2014) dan Bank Syariah Mega Indonesia (2015-2016). Adapun perusahaan dengan nilai retained earning to total 
asset terendah selama periode pengamatan adalah Bank Syariah Bukopin (2012 dan 2015), BJB Syariah (2013), Bank Syariah Mega Indonesia (2014), dan Maybank Syariah Indonesia (2016).

Perusahaan dengan nilai earning before tax to total asset terbesar selama periode pengamatan adalah Bank Syariah Mega Indonesia (2012 dan 2015), Maybank Syariah Indonesia (2013-2014) dan BNI Syariah (2016). Adapun perusahaan dengan nilai earning before tax to total asset terendah selama periode pengamatan adalah BJB Syariah (2012), Bank Victoria Syariah (2013-2014) dan Maybank Syariah Indonesia (2015-2016).

Perusahaan dengan nilai book value of total equity to book value of total debt terbesar selama periode pengamatan adalah Bank Panin Syariah (2012), Maybank Syariah Indonesia (2013-2015) dan BCA Syariah (2016). Adapun perusahaan dengan nilai book value of total equity to book value of total debt terendah selama periode pengamatan adalah Bank Syariah Bukopin (2012), Bank Muamalat Indonesia (2013), BRI Syariah (2014), dan Bank Syariah Mega Indonesia (2015-2016).

Berikut ini disajikan besarnya Z-score dan klasifikasi kesehatan keuangan bank umum syariah di Indonesia pada periode 2012-2016.

Tabel 3. Z-Score dan Klasifikasi Kesehatan Keuangan Bank Umum Syariah di Indonesia pada Periode 2012-2016

\begin{tabular}{|c|c|c|c|c|c|c|c|c|c|c|c|}
\hline \multirow{2}{*}{ No. } & \multirow{2}{*}{ Bank } & \multicolumn{2}{|c|}{2012} & \multicolumn{2}{|c|}{2013} & \multicolumn{2}{|c|}{2014} & \multicolumn{2}{|c|}{2015} & \multicolumn{2}{|c|}{2016} \\
\hline & & Z-score & Kategori & Z-score & Kategori & Z-score & Kategori & Z-score & Kategori & Z-score & Kategori \\
\hline 1 & Bank Muamalat Indonesia & 2,04 & Grey Area & 1,68 & Grey Area & 2,02 & Grey Area & 1,78 & Grey Area & 1,69 & Grey Area \\
\hline 2 & Bank Syariah Mandiri & 1,75 & Grey Area & 1,80 & Grey Area & 2,39 & Grey Area & 2,37 & Grey Area & 2,56 & Grey Area \\
\hline 3 & Bank Syariah Mega Indonesia & 2,06 & Grey Area & 1,82 & Grey Area & 1,87 & Grey area & 3,25 & Sehat & 3,68 & Sehat \\
\hline 4 & BRI Syariah & 1,59 & Grey Area & 1,66 & Grey Area & 1,78 & Grey area & 2,49 & Grey Area & 2,59 & Grey Area \\
\hline 5 & Bank Syariah Bukopin & 1,41 & Grey Area & 1,71 & Grey Area & 2,51 & Grey area & 2,22 & Grey Area & 2,46 & Grey Area \\
\hline 6 & Bank Panin Syariah & 4,42 & Sehat & 3,73 & Sehat & 2,88 & Sehat & 2,86 & Sehat & 2,94 & Sehat \\
\hline 7 & BJB Syariah & 2,88 & Sehat & 2,27 & Grey Area & 2,79 & Sehat & 3,42 & Sehat & 2,34 & Grey Area \\
\hline 8 & Bank Victoria Syariah & 4,27 & Sehat & 3,93 & Sehat & 3,39 & Sehat & 2,84 & Sehat & 2,27 & Grey Area \\
\hline 9 & BCA Syariah & 3,69 & Sehat & 3,15 & Sehat & 3,92 & Sehat & 4,89 & Sehat & 4,79 & Sehat \\
\hline 10 & BNI Syariah & 2,35 & Grey Area & 1,91 & Grey Area & 2,23 & Grey area & 2,33 & Grey area & 2,55 & Grey area \\
\hline 11 & Maybank Syariah Indonesia & 1,62 & Grey Area & 4,65 & Sehat & 4,78 & Sehat & 3,69 & Sehat & 3,87 & Sehat \\
\hline
\end{tabular}

(Sumber: Data diolah, 2017) 
Berdasarkan tabel 3 tersebut, bank umum syariah yang mencapai Z-score tertinggi di tahun 2012 adalah Bank Panin Syariah dengan nilai sebesar 4,42. Hal tersebut terjadi karena di tahun tersebut, Bank Panin Syariah tercatat mencapai book value of equity to book value of total debt tertinggi di antara bank umum syariah lainnya. Sementara itu, Zscore terendah di tahun 2012 diperoleh Bank Syariah Bukopin dengan nilai sebesar 1,41. Hal tersebut terjadi karena di tahun tersebut, Bank Syariah Bukopin mencatatkan retained earning to total asset dan book value of equity to book value of total debt terendah di antara bank umum syariah lainnya.

Di tahun 2012, terdapat tujuh bank umum syariah yang berada dalam grey area, yaitu Bank Muamalat Indonesia, Bank Syariah Mandiri, Bank Syariah Mega Indonesia, BRI Syariah, Bank Syariah Bukopin, BNI Syariah, dan Maybank Syariah Indonesia. Sementara empat bank umum syariah lainnya, yaitu Bank Panin Syariah, BJB Syariah, Bank Victoria Syariah, dan BCA Syariah dikategorikan sebagai perusahaan yang sehat. Di tahun tersebut, perusahaan yang dikategorikan masuk ke dalam grey area tercatat memiliki nilai rasio working capital to total asset dan book value of equity to book value of total debt yang lebih rendah daripada perusahaan yang dikategorikan sehat.

Di tahun 2013, Maybank Syariah Indonesia menjadi bank umum syariah dengan Zscore tertinggi, yakni dengan nilai sebesar 4,654 karena berhasil mencatatkan nilai working capital to total asset, earning before tax to total asset dan book value of equity to book value of total debt tertinggi di antara bank-bank umum syariah lainnya. Sementara itu, Z-score terendah di tahun 2013 diperoleh BRI Syariah dengan nilai sebesar 1,661. Hal tersebut terjadi karena di tahun tersebut, BRI Syariah mencatatkan nilai working capital to total asset, retained earning to total asset, earning before tax to total asset dan book value of equity to book value of total debt yang cenderung lebih rendah daripada bank-bank umum syariah lainnya.

Terdapat tujuh bank umum syariah yang diklasifikasikan berada dalam grey area di tahun 2013, yaitu Bank Muamalat Indonesia, Bank Syariah Mandiri, Bank Syariah Mega Indonesia, BRI Syariah, Bank Syariah Bukopin, BJB Syariah, dan BNI Syariah. Sementara empat bank umum syariah lainnya, yaitu Bank Panin Syariah, Bank Victoria Syariah, BCA Syariah, dan Maybank Syariah Indonesia dikategorikan berada dalam kondisi yang sehat. Di tahun tersebut, bank-bank umum syariah yang sehat tersebut tercatat memiliki nilai working capital to total asset dan book value of equity to book value of total debt yang cenderung lebih besar daripada nilai yang dicatatkan oleh bank umum syariah lainnya yang berada di grey area. 
Di tahun 2014, bank umum syariah yang mencapai Z-score tertinggi adalah Maybank Syariah Indonesia dengan nilai sebesar 4,780 karena berhasil mencatatkan nilai working capital to total asset, earning before tax to total asset dan book value of equity to book value of total debt yang paling besar di antara bank-bank umum syariah lainnya. Sementara itu, Z-score terendah di tahun 2014 dicatatkan oleh BRI Syariah dengan nilai sebesar 1,783. Hal tersebut terjadi karena bank tersebut meraih book value of equity to book value of total debt terendah di antara bank-bank umum syariah lainnya.

Jumlah bank umum syariah yang berada dalam grey area mengalami penurunan di tahun 2014, yakni menjadi enam bank yang terdiri dari Bank Muamalat Indonesia, Bank Syariah Mandiri, Bank Syariah Mega Indonesia, BRI Syariah, Bank Syariah Bukopin, dan BNI Syariah. Jumlah bank umum syariah yang dikategorikan sehat juga mengalami kenaikan menjadi lima bank, yaitu yang terdiri dari Bank Panin Syariah, BJB Syariah, Bank Victoria Syariah, BCA Syariah, dan Maybank Syariah Indonesia. Di tahun tersebut, perusahaan yang dikategorikan berada dalam grey area cenderung memiliki book value of equity to book value of total debt yang cenderung lebih rendah daripada bank-bank umum syariah lainnya yang dikategorikan sehat.

Di tahun 2015, Z-score tertinggi dicapai oleh BCA Syariah dengan nilai sebesar 4,898. Hal tersebut terjadi karena di tahun tersebut, BCA Syariah meraih nilai working capital to total asset dan book value of equity to book value of total debt yang cenderung lebih besar daripada sebagian besar pesaingnya. Sementara itu, Bank Muamalat Indonesia justru mencatatkan Z-score terendah di antara para pesaingnya di tahun 2015, yakni dengan nilai 1,784 . Hal tersebut terjadi karena bank tersebut mencatatkan nilai working capital to total asset, retained earning to total asset, earning before tax to total asset dan book value of equity to book value of total debt yang cenderung lebih rendah dari sebagian besar pesaingnya.

Jumlah bank umum syariah yang dikategorikan berada dalam grey area kembali mengalami penurunan di tahun 2015, yakni menjadi lima bank yang terdiri dari Bank Muamalat Indonesia, Bank Syariah Mandiri, BRI Syariah, Bank Syariah Bukopin, dan BNI Syariah. Jumlah bank umum syariah yang berada dalam kondisi sehat pun kembali mengalami kenaikan menjadi enam bank, yaitu yang terdiri dari Bank Syariah Mega Indonesia, Bank Panin Syariah, BJB Syariah, Bank Victoria Syariah, BCA Syariah, dan Maybank Syariah Indonesia.

Bank umum syariah yang mencapai Z-score tertinggi di tahun 2016 adalah BCA Syariah, yaitu dengan nilai sebesar 4,796 karena memiliki nilai book value of equity to 
book value of total debt tertinggi di antara para pesaingnya. Sementara itu, Z-score terendah di tahun 2016 dicatatkan oleh Bank Muamalat Indonesia, yaitu dengan nilai sebesar 1,691. Hal tersebut terjadi karena bank tersebut mencatatkan nilai working capital to total asset terendah dibandingkan dengan bank-bank umum syariah lainnya di tahun tersebut.

Di tahun 2016, jumlah bank umum syariah yang berada dalam grey area justru mengalami kenaikan menjadi tujuh bank, yakni yang terdiri dari Bank Muamalat Indonesia, Bank Syariah Mandiri, BRI Syariah, Bank Syariah Bukopin, BJB Syariah, Bank Victoria Syariah, dan BNI Syariah. Sementara itu, jumlah bank umum syariah yang dikategorikan sehat justru mengalami penurunan menjadi empat bank, yaitu yang terdiri dari Bank Syariah Mega Indonesia, Bank Panin Syariah, BCA Syariah, dan Maybank Syariah Indonesia.

Berdasarkan hasil analisis financial distress yang telah diuraikan sebelumnya, bank umum syariah yang secara konsisten dikategorikan sehat pada periode 2012-2016 adalah Bank Panin Syariah dan BCA Syariah. Di tahun 2012, Bank Panin Syariah bahkan berhasil meraih Z-score tertinggi di antara para pesaingnya. Adapun BCA Syariah berhasil meraih $Z$-score tertinggi di antara para pesaingnya selama dua tahun berturut-turut, yaitu pada tahun 2015 dan 2016. Sementara itu, bank umum syariah yang selalu berada di grey area selama periode tersebut adalah Bank Muamalat Indonesia, Bank Syariah Mandiri, BRI Syariah, Bank Syariah Bukopin dan BNI Syariah. Z-score terendah diraih oleh Bank Syariah Bukopin di tahun 2012, BRI Syariah di tahun 2014, serta Bank Muamalat Indonesia di tahun 2013, 2015 dan 2016.

\section{KESIMPULAN DAN SARAN}

\section{Kesimpulan}

Berdasarkan hasil penelitian ini, dapat disimpulkan hal-hal sebagai berikut.

1. Bank umum syariah yang dikategorikan sehat terdiri dari empat bank di tahun 2012, empat bank di tahun 2013, lima bank di tahun 2014, enam bank di tahun 2015, dan empat bank di tahun 2016.

2. Bank umum syariah yang berada di dalam grey area terdiri dari tujuh bank di tahun 2012, tujuh bank di tahun 2013, enam bank di tahun 2014, lima bank di tahun 2015, dan tujuh bank di tahun 2016.

3. Bank umum syariah yang secara konsisten dikategorikan sehat selama periode 20122016 adalah Bank Panin Syariah dan BCA Syariah. 
4. Bank umum syariah yang selalu berada di dalam grey area selama periode 2012-2016 adalah Bank Muamalat Indonesia, Bank Syariah Mandiri, BRI Syariah, Bank Syariah Bukopin dan BNI Syariah.

\section{Saran}

Berdasarkan kesimpulan di atas, berikut ini disarankan hal-hal yang dapat dipertimbangkan oleh pihak-pihak yang terkait.

1. Bank umum syariah yang secara konsisten dikategorikan berada dalam kondisi keuangan yang sehat diharapkan dapat senantiasa mempertahankan atau bahkan meningkatkan kinerja keuangannya di masa mendatang.

2. Bank umum syariah yang seringkali berada dalam grey area diharapkan dapat memperbaiki kinerja keuangannya dengan cara meningkatkan modal kerja dan profitabilitasnya, serta mengurangi proporsi utang dalam modal yang digunakannya.

3. Dalam menentukan keputusan investasi, para investor disarankan untuk turut mempertimbangkan Z-score dari perusahaan yang bersangkutan ataupun rasio keuangan penyusun Z-score tersebut secara parsial yang terdiri dari working capital to total asset, retained earning to total asset, earning before tax to total asset dan book value of equity to book value of total debt agar dana yang diinvestasikannya dapat disalurkan ke perusahaan berprospek baik dengan kondisi keuangan yang sehat.

\section{DAFTAR PUSTAKA}

Almilia, L.S. 2006. Prediksi Kondisi Financial Distress Perusahaan Go-Public dengan Menggunakan Analisis Multinomial Logit. Jurnal Ekonomi dan Bisnis. 12(1).

Altman, E.I. 1968. Financial Ratios, Discriminant Analysis and the Prediction of Bankruptcy. The Journal of Finance. 23(4): 589-609.

. 1983. Corporate Financial Distress: A Complete Guide to Predicting, Avoiding and Dealing with Bankruptcy. Wiley and Sons. New York.

., Y.H. Eom. dan D.W. Kim. 1995. Failure Prediction: Evidence from Korea. Journal of International Financial Management and Accounting. 6(3): 230-249.

Audina, B.P. dan Sufyati. 2018. Pengaruh Financial Leverage, Struktur Modal dan Total Asset Growth terhadap Financial Distress pada Perusahaan Subsektor Pulp dan Kertas yang Terdaftar di Bursa Efek Indonesia. Jurnal Ilmu Manajemen Oikonomia. 14(1): 76-90.

Bank Indonesia. 2008. Perbankan Syariah. https://www.bi.go.id/id/perbankan/syariah/ Contents/Default.aspx. 10 September 2017 (16:19). 
Choirina, P.M. dan E.N.A. Yuyetta. 2015. Analisis Faktor-Faktor yang Mempengaruhi Probabilitasw Financial Distress Perbankan Indonesia. Diponegoro Journal of Accounting. 4(2): 1-9.

Damodaran, A. 2001. Corporate Finance: Theory and Practice. $2^{\text {nd }}$ International Edition. John Wiley \& Sons. New York.

Harahap, S.S. 2010. Analisis Kritis atas Laporan Keuangan. RajaGrafindo Persada. Jakarta.

Manurung, A.H. 2012. Teori Keuangan Perusahaan. Adler Manurung Press. Jakarta.

Rodoni, A. dan H. Ali. 2014. Manajemen Keuangan Modern. Mitra Wacana Media. Jakarta.

Supardi, S.M. 2003. Validitas Penggunaan Z Score Altman untuk Menilai Kebangkrutan pada Perusahaan Perbankan yang Go Public di Bursa Efek Jakarta. KOMPAK. (7): 68-93.

Undang-Undang Republik Indonesia Nomor 10 Tahun 1998. Perbankan. 10 November 1998. Lembaran Negara Republik Indonesia Tahun 1998 Nomor 182. Jakarta.

Whitaker, R.B. 1999. The Early Stages of Financial Distress. Journal of Economics and Finance. 23(2): 123-132.

Wruck, K.H. 1990. Financial Distress, Reorganization and Organizational Efficiency. Journal of Financial Economics. 27(2): 419-444. 